\title{
PAST THE MEMOIR
}

\author{
Winifred Dolan beyond the West End
}

\section{Lucie Sutherland}

As an actress, producer and teacher, Winifred Dolan (1867-1958) had a long and varied working life. Leaving professional theatre in 1904, Dolan later called her time as an actress 'years of rich experience and testing endeavour'. ${ }^{1}$ These words appear in her memoir, A Chronicle of Small Beer, written in 1949 for private circulation within the school where Dolan had been employed as a drama teacher and amateur theatre producer for almost three decades. Here an initial career in professional theatre is positioned as a constructive contribution to subsequent work in education; 'experience' and 'testing' imply the formative significance of time spent working in the West End. That time is not the epitome of a professional life; rather, it informs theatre production by Dolan in a different professional realm, later in the twentieth century.

Dolan did not achieve any form of celebrity status as a professional actress. Born in Leeds in 1867 , she was a student and then a student teacher at Leeds Girls' High School by the late 1880s, where as an amateur actor and producer she founded a drama society. In April 1891 she joined Sarah Thorne at Margate to receive some training, and by October she was employed as an understudy by actor-manager George Alexander, at the St James's Theatre in London; her first credited role was the following year as the maid, Rosalie, in the premiere of Lady Windermere's Fan. From this point she worked for Alexander and other West End and touring managers for just over a decade. However, employment was erratic, as was the alternative work sometimes offered by Alexander, to assist with play selection and theatre management. Early in 1904 Dolan moved on to a post as London Secretary for the Women's Unionist Association (an adjunct of the Conservative Party), and when the organisation was disbanded in 1917 she became a teacher at 
the Catholic New Hall School (then with an all-female student body), in Chelmsford. She was responsible for the introduction of regular drama work for the students, a feature that continues to be cited as characteristic of the school. ${ }^{2}$ Dolan was offered a home there, even into retirement, and she developed a range of materials on theatre production for teaching purposes, as well as Small Beer. These materials have been housed at the Victoria and Albert Museum since 2004, and an edited version of the memoir was published in 2010, signalling recognition, more than half a century after her death, of specific contributions to the professional theatre industry and to the evolution of drama teaching.

Alongside production manuals, prompt books, set designs and Small Beer, there are included a number of plays written by Dolan, many for young actors; for example, an adaptation of Toad of Toad Hall. A very small number of letters - those directly quoted in the memoir - and some pictures are also present. ${ }^{3}$ Looking across the collection, the majority of the material is there as a guide to future theatre makers, and the ephemera - letters and photographs - serve to consolidate the account of professional work outlined in Small Beer. This kind of evidence is rare; while it is possible to examine the published and unpublished autobiographical accounts and personal papers of many prominent theatre workers, a range of practice-focused manuals alongside a memoir, rearticulating the use of theatre in a pedagogic context, is a unique resource. Dolan's working life might not seem characteristic for an actress of the period, but in fact it points to the dexterity required of those actresses who did not achieve celebrity or consistent employment in theatre. Her life and collection are evidence of the range of skills that could be acquired in the West End to be redeployed in other sectors.

Surveying the Winifred Dolan Collection allows for analysis of the individual female subject, without her working practices becoming obscured by attention to more prominent West End workers. While Small Beer refers to the celebrities whom Dolan encountered, the collection is predominantly concerned with the way in which its author translated early work into theatre making at New Hall, promoting her aptitude as an independent producer and teacher. The school environment provided space for Dolan to construct a distinct form of professional identity that was not contingent upon what Christine de Bellaigue has described as 'an ideal-type model that simply reproduces the ways in which late-nineteenth century professional men sought to define themselves', querying 'the idea of women storming, or slipping in to, the professional citadel' (de Bellaigue, 2001: 965). 
The production manuals she created display a reliance upon skills honed through West End work, but clearly represent Dolan as a producer who had established her own 'citadel' and who sought through her writing to pass on, and so to sustain, the practices she developed for New Hall so that students and staff of that school would, beyond the point of her retirement in the 1940s, continue the drama work she had instituted. In comparison, Small Beer is presented as having a less explicit relationship to her work there, describing the development of skills in acting and production, but not their application within the school environment. This creates a form of distance between her later working life and early professional experience, a distance that is explicitly insisted upon in the Foreword to Small Beer: '[n] ow that I am a very old woman I find that I can look back across the chasm of 60 years with a curious degree of detachment as though the story was that of another person I once knew' (Dolan, 2010: Foreword, n.p.).

This effort to separate an earlier self historicises professional work in the theatre, allowing the idea of perspective and authority over past experience and its subsequent influence to come to the fore. As recent work on the actress and autobiography has made explicit, the memoir is a form of autobiographical writing that provides space for the writer to present themselves as actor, not an object (Bratton, 2003: 101), and this is exemplified by the perspective Dolan takes upon her former career. Dolan was not alone in portraying her experience of the theatre industry at the end of the nineteenth century in this way. ${ }^{4}$ An actress employing this technique was representing her work on her own terms, rather than solely inhabiting what Maggie B. Gale - in relation to the autobiographical writing of Lena Ashwell - has described as 'a history of English theatre, a history largely written and inhabited by men at the point at which she found herself looking autobiographically back on her own contributions' (Gale, 2004: 99). Mapping the narrative of Small Beer, it is evident that the aim is to present a constructive, active portrait of an earlier working life; while the treatment of Dolan by industry leaders is referenced, the structure and focus of the memoir foregrounds her developing expertise. Dolan uses Small Beer to advertise, for a New Hall readership - the original volume includes the phrase 'For private circulation only' - her presence in and experience of West End theatre, placing her own endeavour at the centre of the narrative.

The brief summary so far of a working life, and its legacy as the collection, provides an initial sense of both the professional expertise and personal interests we can attribute to Dolan. It also begins to unpick 
the range of evidence left behind, to assess the skills she developed as an actress, that were of value beyond the theatre industry. At New Hall, control over drama and performance work was far in excess of the professional agency experienced by Dolan in the West End. Therefore, a return to teaching was more than the aftermath of an acting career and recourse to a field which, by the early twentieth century, had long been recognised as a feasible professional sphere for middle-class women in need of regular income. The collection allows us to dig down into creative and pedagogic practice, the precise detail of her work as a teacher, and to examine how her working knowledge of professional theatre was used to mount full-length productions on New Hall's purposebuilt stage. This chapter explores the way in which Dolan developed performance at the school in response to her work in the West End. She ceased all work in professional theatre in 1904, unable to secure regular employment as an actress or administrator in the theatrical mainstream. However, she did then use expertise honed within the theatre industry to mount an ambitious repertoire of Shakespeare and drama written by her for young people. Dolan was able to foreground her own expertise and creative ambition, adapting the kind of creative autonomy witnessed within the actor-manager system to work as an independent producer in a school environment.

\section{West End work on and beyond the stage}

Space for individual professional development at New Hall contrasted with the limits imposed upon the work Dolan could take on for West End managements. This is exemplified in correspondence from Alexander to Dolan:

My dear Winifred,

Candidly my thoughts about the secretary work in the autumn only spring from my wish to put you well on your feet - I am delighted to hear you are on a firmer footing. If you had been a man I should have given you the push this way ages ago with a view to you becoming my acting manager later on, but you see that wouldn't be possible. ${ }^{5}$

Alexander's attitude as actor-manager represents the 'demarcationary closure' (Witz, 1992: 47) that influenced the opportunities afforded to women in white-collar professional spheres, including theatre management, by the final decades of the nineteenth century. This is a useful concept in relation to Dolan's experience, as obvious restrictions were 
placed upon opportunities for her own professional progress. More specifically, sociologist Anne Witz notes:

Gendered strategies of demarcationary closure describe processes of inter-occupational control concerned with the creation and control of boundaries between gendered occupations in a division of labour. They turn not upon the exclusion, but upon the encirclement of women within a related but distinct sphere of competence in an occupational division of labour and, in addition, their possible (indeed probable) subordination to male-dominated occupations. (Witz, 1992: 47)

This process may be perceived in practice with Dolan, where progress in the field of theatre management was obstructed on the grounds of gender, while a career in education involving the construction and management of a theatre space was feasible. Dolan could re-apply theatre industry practice in a field where women had an established professional status by the early twentieth century, sometimes in a very direct sense: she hired West End personnel to enhance the level of professionalism associated with New Hall productions, specifically a London-based scenic artist and a retired Drury Lane carpenter to develop and construct sets for annual Shakespeare productions from the mid-1920s into the 1930s (Canonesses, 2012: 41).

Although prominent West End personalities are frequently mentioned in the memoir - Ellen Terry is foregrounded as a friend and inspiration, and Alexander is a sustained presence since she worked mostly for him - personal professional development is the focus. So, it is made clear that while Terry introduced Dolan to the 'card' system - how to use a business card listing the St James's Theatre as her address to gain free entry to other West End productions, to develop her experience of repertoire and performance technique - it was Dolan who chose to capitalise upon this by regular theatregoing. ${ }^{6}$ Similarly, while Alexander approved of her desire to watch each performance from the prompt corner as a junior member of the St James's Company, it was her idea to do this in the first place. ${ }^{7}$

She consistently features her pattern of promoting her own constructive practice and individual agency, although the memoir does not discount the informal networks that initially facilitated her acting career. Dolan admits that family relationships ultimately propelled her into employment; she met Henry Irving and Ellen Terry through her uncle, the poet Alfred Austin. ${ }^{8}$ This is one example of the particular habitus to Dolan's early life, the social processes contributing to middle-class 
behaviours and social networks that afforded introductions to influential theatre professionals. ${ }^{9}$ Such networks frequently characterised the entrance of middle-class women into the theatre profession by the late nineteenth century. The following letter demonstrates the informal, influential networks that could provide a route from training into professional work:

Dear Alfred Austin,

If your niece is doing nothing I will attach her to our staff as an understudy and give her a guinea a week so that she could get an idea of London theatre, and if I found her intelligent I wd. try to give her a small part later on. Telegraph me if you think she would care for this.

Yours sincerely,

George Alexander. ${ }^{10}$

Small Beer admits personal advantages, but these are combined with details of how Dolan built upon opportunities to support herself; independent action to propel developing experience and employment is emphasised as paramount:

So I telegraphed "Yes" to my Uncle, and to Mr. Alexander that I was on my way, wrote the news to my mother, packed my cabin trunk and was in London early next morning, presenting myself at the stage door of the St. James's Theatre about midday. ${ }^{11}$

Dolan makes space to describe with precision her own endeavour in response to the communications between Alexander and Austin.

In their critical edition of The Importance of Being Earnest and its 1895 premiere, Joseph Donohue and Ruth Berggren describe the type and level of success experienced by Dolan, citing her career as a particular example of the kind of theatre professional who is almost lost to the historical record (certainly the case before the collection was acquired by the Victoria and Albert Museum). Their focus upon Dolan is prompted by her relationship to the play not as an actress, but as typist for an 1898 copy based upon Alexander's house script and used for the first published version (Donohue and Berggren, 1995: 75-6). They note that the entry for Dolan in the Dramatic and Musical Directory of 1893 describes her range as 'juv. ingen. light com.', which expresses her versatility and usefulness for a manager, but also her relative anonymity (Donohue and Berggren, 1995: 76). Between 1891 and 1899 Dolan appeared in a number of St James's productions in minor roles, including Rosalie in Lady Windermere's Fan (1892), Lady Orreyed in The Second Mrs. Tanqueray 


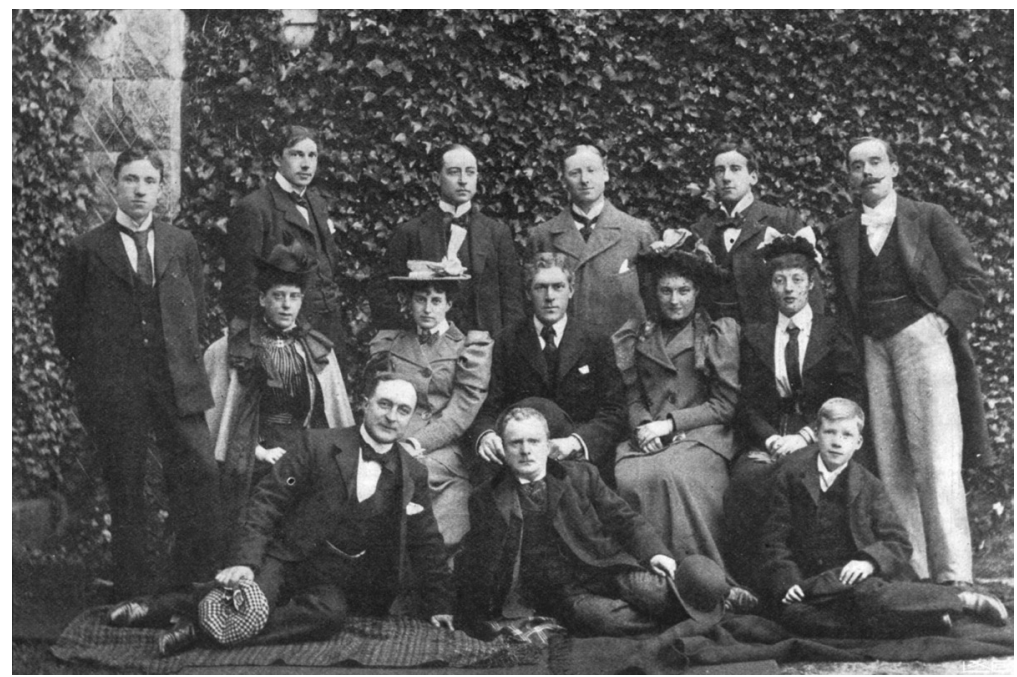

5 The St James's Company at Balmoral, 16 September 1895. Winifred Dolan is seated, second row, far right. George Alexander is second row centre.

(at the first cast change, 1893), Miss Hickson in Liberty Hall (1895) and Margaret in Much Ado About Nothing (1898). However, she did not progress to more prominent roles within the company, and was frequently relegated to understudy work, which was 'only valuable as further practice, not for publicity'. ${ }^{12}$ Interestingly, late in 1892 Edith Craig joined the St James's Company and took on the kind of minor roles that Dolan had been given. Most often, therefore, Dolan took over parts first performed by other actresses, or understudied, resulting in a lack of real opportunity for career development as an actress.

The memoir demonstrates that while class and social relationships supported entry to the profession, gender and a kind of outsider status simultaneously limited professional development: 'One of the difficulties I experienced as a lone wolf on the stage was that, not belonging to any theatrical family and, as a woman, unable to drink at bars, I never knew of a coming production till I read of it in the Daily Telegraph. ${ }^{13}$ However, when 'resting' between acting roles, Dolan frequently took on work associated with the processes of theatre management and production, and she describes this work in detail. Significantly, the more straightforward administrative work she took on, like the preparation of the Earnest 
script, is not mentioned. Much of the managerial and production work was prompted by the absence of Alexander's private secretary, R. G. Legge, from the St James's Theatre. For example, in 1896 Legge became acting manager at the Royalty Theatre, when Alexander took a short lease on the venue to produce the farcical comedy His Little Dodge. ${ }^{14}$ Dolan describes the offer that she should take on the role of private secretary for a limited period, Alexander asserting that this was 'on the understanding that if and when I give up The Royalty you have kept his [Legge's] seat warm for him to come back to'. ${ }^{15}$ Between 1895 and 1904 Dolan was then asked to undertake a range of production work, for example as Alexander's representative at rehearsals for the national tour of Dodge, which had been optioned by Ben Greet. ${ }^{16}$ During the 189 os Dolan also travelled to Paris on at least two occasions to watch productions and subsequently to advise Alexander on whether to option plays. ${ }^{17}$

The trajectory of her work at the St James's Theatre suggests a growing reliance by Alexander upon Dolan in the areas of play selection and production development. During this period this was the type of work still undertaken almost exclusively by men within the West End realm, with few exceptions. ${ }^{18}$ When covering for Legge, the kind of support offered by Dolan to the ostensibly autonomous actor-manager was integral to management:

I'll describe a typical timetable as experience evolved it:

First I had to be at the two theatres for the morning's letters \& take them to Pont Street by nine o'clock - this meant my day started about $8 \mathrm{am}$ ! I only quitted my post for a quick lunch at some restaurant (tea at the office) and left it around 6 or 6.30 p.m Home to dinner. Back at 7.30 p.m. \& on duty until close on midnight. Da capo except on Sundays, for six months as it turned out. Pretty strenuous! My duties included: having taken instructions concerning the letters, return to St. James' to answer them; to keep G.A. posted as to his various engagements; writing his speeches when he was called upon to make them; to interview endless people on various matters; $\&$, as his reader of plays, to keep abreast with a tide never less than $2 \mathrm{ft}$ high \& on my own responsibility reject or, if I were in doubt as to a "possible one", submit a scenario of it upon which he decided to read it, or not! [...] G.A. was certainly giving me chances no woman had had at that time! ${ }^{19}$

Dolan does not critique an actor-manager system that required such extensive support from unacknowledged personnel. Rather, she advertises her achievement in fulfilling designated tasks, and the benefits to her of taking on the work. She is an active participant in the evolution 
of her career, and the memoir indicates the care taken by its author to maintain a sense of her own agency in relation to the authority of the actor-manager. Thus when recounting that in 1896 Alexander asked her to enquire about English-language rights to the Henri Lavedan comedy Le Prince d'Aurec while she was in Paris, Dolan explains that she was already in the city to further her understanding of French theatre practice, taking classes with the Comédie Française actress Jenny Thénard. ${ }^{20}$ Small Beer resists any impression that Dolan was simply a passive subordinate when employed in the actor-manager system.

Alexander did eventually offer her a long-term post as his private secretary in 1904, but this was not secure enough for a woman alert to the need for long-term employment in order to ensure financial security: 'Would it be permanent this time? Would my health stand the strain of those six months I have described, stand it for years? I refused.'21 Again, Dolan emphasises her own participation in the development (and indeed the termination) of her career in the West End. The way her own initiative is foregrounded in Small Beer, alongside the technically specific manuals that make up the rest of the collection, indicates proactive behaviour translated into a career that offered more security and eventually a more senior role as producer:

If I failed - not altogether, I think? - I am inclined to wonder whether my "line" lay less in acting than in "producing". But, you see, I wasn't a MAN - and in the 9o's - ! Could it be that Providence permitted me this training that I might one day be of some little use to New Hall? If so, I deny I failed. ${ }^{22}$

As a woman who had a limited number of options available to her on ceasing to work as a professional actress, Dolan created a collection of resources to demonstrate the manner in which she self-consciously built upon West End practice to create a distinct identity as a teacher and producer at the school.

\section{Drama in schools, drama schools and Dolan at New Hall}

Dolan's later work was made possible by a number of factors alongside her experience in the theatre industry; again work was to some extent fostered by informal family networks. A form of 'patronage-based recruitment' (de Bellaigue, 2001: 964) more common in the teaching profession up to the mid-nineteenth century characterised the employment gained by Dolan at New Hall: ${ }^{23}$ her sister was Prioress of the 
community attached to the school and, unlike her predecessor, supported the introduction of regular drama work (Tuckwell, 2006: 153). However, Dolan was a qualified teacher after her time at Leeds Girls' High School, and she was one of a number of lay teachers who joined New Hall on a permanent basis so that it could meet the requirements of the Education Act 1918 (Tuckwell, 2006: 157). In looking beyond family relationships to working practices, it is possible to see a sophisticated form of professional development in evidence, combining teaching experience and West End expertise.

An analysis of the collection defines its author as a dominant producer-teacher figure, so much so that Dolan coordinated the construction of a permanent theatre space at New Hall, the Eaton Theatre, in $1925 .{ }^{24}$ As subsequent examples from the collection will make clear, Dolan used her previous professional experience to develop a precise approach to drama in education: practice by amateurs guided by professional standards. Her work at New Hall was not without precedent, however; as a qualified teacher she leveraged the tradition of drama in Catholic school environments and a growing interest in embedding performance practice within formal education to introduce professional standards in her drama teaching and theatre production work at New Hall.

There is evidence of drama work in monastery schools from the tenth century onwards, in Europe. This was not a straightforward and sustained presence, however, and in England it was a practice compromised by the anti-theatrical prejudices of Reformation culture. New Hall School, founded in 1642 and based at Liège until 1799, had its roots in the Augustinian tradition, which in relation to formal, Catholic school education demonstrated features including a focus upon developing and sustaining community - an aim that could potentially be fostered by collaborative performance practice - alongside distinct anti-theatrical prejudice. $^{25}$ The long-term (if contested) presence of some drama work in European Catholic schools over a number of centuries, in spite of this historical suspicion around the work of theatres themselves, is therefore one contextual factor that contributed to the kind of work Dolan was able to undertake at New Hall. Also, in the wake of the 1870 and 1902 Education Acts and increased state involvement in all schools - including faith schools - Catholic educational establishments were committed to the preservation of authority to determine curricula, again providing space for Dolan to develop drama work. ${ }^{26}$

These factors allowed an essential flexibility to provision in the early twentieth century so that the priorities of an individual school and an 
individual teacher-practitioner could be foregrounded. This development of drama work within a girls' school also echoed some characteristics of the new London drama schools, which fostered the idea that training provided women with particular skills applicable beyond the stage. The Academy of Dramatic Art, after its foundation in 1904, and with its majority female intake, was perceived in part to be a kind of finishing school for middle- and upper-class young women in the early decades of the twentieth century; a perception encouraged by some features of the curriculum, such as the teaching of French language alongside classes in acting technique and speech. This risked obscuring the role of the school as a training ground for professional actors and actresses - the stated aim of the industry leaders who were integral to the establishment of each school, including the actor-managers Frank Benson (Central School of Speech and Drama) and Beerbohm Tree ([R]ADA). But it did signal how drama work could play a valuable role within education, tied as it was in these new institutions to other kinds of vocational training and skills development, in a combination that was particularly appealing to female students at the time. ${ }^{27}$ The increasing prevalence of drama work in permanent scholastic institutions was representative of a desire to consolidate the idea of theatre as a regulated and a reputable professional arena.

Although Dolan ended her career as an actress just as these drama schools were being established, she had worked with figures who supported their foundation, such as Tree and Alexander, and the collection asserts that she shared with these individuals a desire to promote, in an educational context, the rigour to be found in professional theatre:

We, at New Hall, have for some years past set up a standard of acting Shakespeare which we humbly hope approximates to the worthiest efforts elsewhere. A gifted amateur is to be preferred to a bad professional, because the weaknesses of the one may be condoned while the vices of the other can not be too strongly condemned. ${ }^{28}$

The concept of the 'worthiest' productions versus the 'bad professional' displays an anxiety about less rigorous sectors of the theatre industry that risked undermining the plausibility of her role as former actress turned independent producer and teacher. While her more prominent West End contemporaries were developing actor training in permanent institutions to enhance the professionalism associated with the theatre industry, Dolan encouraged acting and stage management techniques that aspired to exacting industry standards. 
She refers insistently to her particular personal expertise as a qualification for New Hall practice. In the handwritten 'Shakespeare Coach's Manual', for example, the edits to Macbeth are intrinsically linked to this expertise:

I confess I have taken great liberties with the plays I have produced at New Hall - cutting out whole scenes, shortening speeches, even transposing the order of some scenes to simplify scene-shifting and reduce "waits" between the Acts. For instance, in "Macbeth", after the Tea Interval I have transposed Scenes 1 and 2 of Act iv because the interval gives time to set the heavy sleep walking scene and then the two short scenes England, and Birnam Wood follow together without any injury to the sequence of events. This is an expert job if balance, plot, etc. are not to suffer, and needs a very professional measure of experience and technique. $^{29}$

Dolan positions her work as both particular to the precise school environment, and as being built upon her professional knowledge. Her focus upon pre-existing dramatic texts translated to performance, and not on drama as a route to personal expression or well-being as is encountered in many Theatre in Education initiatives later in the twentieth century, also demonstrates a close correlation to a mainstream theatre model. Dolan's method was structured for a precise institutional framework, but that did not mean it was a wholly unique way of working, based as it was upon a range of established factors including personal expertise in professional theatre, and wider, increasing attention to drama as a discrete area for study.

\section{Amateur theatre and professional expertise}

The presence and practice of Dolan within a school environment also exemplified frequent links between professional theatre and amateur production in the first decades of the twentieth century. Dolan's work at the school was essentially a branch of amateur theatre based upon the perseverance of established practice rather than innovation, unlike, for example, some of the amateur work that had been integral to the emergence of 'New Drama' earlier in the century. Attention to her work provides an alternative to 'accounts of the twentieth century [which] have tended to focus on tracing the evolution and continuities of the new rather than recognising the parallel continuities of the old' (Cochrane, 2011: 11), a tendency that has, as Claire Cochrane attests, 'contributed to the further disparagement and thus marginalisation of the widely 
practised "not new"' (2011: 11). Dolan explicitly called upon the authority of previous West End work; as a producer - in the collection that word is frequently employed to designate her role - she asserts the value of her own experience, while making amateur theatre a viable and regular feature of a Catholic school education.

Amateur theatre work was not a new experience for Dolan. She had founded an amateur company in Leeds during the $188 \mathrm{os}$, and, as a professional actress, accepted work in prominent amateur productions, for example at Shrewsbury in the Yeomanry Centenary Pageant mounted by Lord Kilmorey in $1895 .{ }^{30}$ On returning to amateur production in a school Dolan developed a particular kind of small theatre environment for revivals of canonical drama and her own plays for young people. Control over every aspect of a production allowed her to maintain engagement through practice with forms of theatre that were in line with her own ideals for drama, informed by aesthetic and religious beliefs. In comparison, in Small Beer she identifies the 'New Drama' movement and syndicated production as developments that were to the detriment of professional theatre repertoire by the final decade of the nineteenth century. The moral imperatives that guided these views are evident in the memoir, and are implicitly linked to the time at which she ended her work in professional theatre in 1904:

So long as the old Queen lived the trend was hardly noticeable, but with the Edwardian age it burst into full bloom. We see the mature fruit today in our Divorce Court lists, in the sex-appeal, strip-tease nudity of our cabaret entertainments, the hysterical worship of film stars[.] $]^{31}$

Identifying the first years of the twentieth century as a tipping point further endorses the implementation of expertise beyond what was, to Dolan, a theatre industry changing for the worse.

Her work sat outside the primary amateur theatre organisations of the early twentieth century - notably the British Drama League - but material in the collection designates a similarity to the movement as a whole with the contribution of a (former) professional theatre worker to amateur production. In the Foreword to her 'Guide to Amateur Theatrical Production', Dolan makes this explicit: 'This little guidebook is respectfully and diffidently offered by one whose professional acquaintance with the stage and her whole-hearted love of it are her sole excuses. ${ }^{32}$ Dolan designates New Hall work as quite consciously a kind of 'pro-am' practice. The overt use of her former career as qualification for this also attests to the way in which autobiographical 
traces are present throughout the collection, signalling the function it performs.

West End work is insistently promoted as one influence upon a complex and developing professional life, but it does not receive extended attention beyond Small Beer. In the 'Guide to Stage Management', Dolan describes her integral role in the evolution of drama work at New Hall, before providing technical specifications for the theatre space. When assessing how West End work is used, the final page of the Foreword to this volume is of particular interest. Here, it is made explicit that early experience has been translated into clear lines of practice, to enhance personal authority as a teacher and producer. The Foreword concludes 'Winifred Dolan, Newnham Paddox, Rugby, 1945' (the school having relocated during wartime), accompanied by a list of sites where she had been employed during her time as a professional actress:

St. James's Theatre

$\left.\begin{array}{ll}\text { Criterion } & " \\ \text { Court } & " \\ \text { Avenue } & " \\ \text { Terry's } & " \\ \text { Daly's } & "\end{array}\right\} 1891-1904$

Underneath this list, Dolan has made handwritten additions, emphasising the authority conferred by a previous career:

Command Performance Balmoral Castle.

Lyceum Theatre

Haymarket

\} Single 'Benefit' performances ${ }^{33}$

Here Dolan provides endorsement of her experience and aptitude serial employment in high-calibre theatres - as a stage manager by listing professional work with London companies. Apart from this listing, there are no references to her West End work in this volume; it is not another version of the memoir. This is a formal summary of an earlier working life, positioned in isolation and in brief, confirming to the user that the author is qualified to create the guide.

Like all the materials in the collection, this demonstrates a sense of professional authority. The volumes on stage management and amateur theatre sit alongside the guide to producing Shakespeare and the 'SceneShifters' Manual', a number of prompt copies, and set design illustrations. Materials are either handwritten or typed, and most often in 
bound volumes. In creating these resources, Dolan echoes the growing prevalence of published technical guides for amateur theatre written by industry professionals and educators. Many of these had a particular focus upon appealing to women, and situating practical drama as suitable for female students. ${ }^{34}$ Once again Dolan is shown to be operating as a woman within a precise environment, creating her own repertoire but demonstrating awareness of parallel developments in drama and theatre work.

Dolan had ultimate authority over productions, but the nature of that authority was quite different to the type assumed by celebrity actresses of her generation, for example Irene Vanbrugh, who also worked frequently at the St James's Theatre during the $1890 .{ }^{35}$ Vanbrugh achieved a form of control over her career through prominent status and regular work in the mainstream theatre industry:

To a woman the profession of acting is one which, provided she has talent and is prepared to work hard, is as satisfactory financially as a woman can have, because, although it is precarious and uncertain, it is independent of others, to a great extent, and is one in which a woman has equal chances with a man - in which her own individuality is her chief asset - in fact, she is dependent upon this for the market value she attains. (Vanbrugh, 1951: 98-9)

As a woman working 'behind the scenes' and performing in minor roles by comparison, Dolan's presence was less prized in the West End marketplace, but the skills developed in that arena were translated into distinct authority and professional agency within a subsequent professional context, and bolstered via strategies such as the listing of sites of employment in the 'Guide to Stage Management'.

Another technique used in Dolan's writing is the inclusion of quotes from other sources summarising the working practices of her former colleagues, thus linking her own expertise, as evident in the creation of the technical guides, with a kind of scholarly procedure in developing materials for the school. Actress and teacher are both represented through this process. In her guide to producing amateur theatre, for example, she includes pre-existing accounts by Bram Stoker and Ellen Terry of how Irving staged Macbeth. Dolan explains her recourse to other texts thus:

Dame Ellen Terry's "Story of my Life" and Bram Stoker's "Personal Reminiscences of Henry Irving" are two volumes packed with instructions for the aspiring actor. Neither being written with any such purpose 
in view, the knowledge is to be gathered by a process of sifting and gleaning. ${ }^{36}$

Experience of West End work and the ideas of well-known theatre industry professionals combine in material that advertises Dolan's own technical expertise, epitomised in the typed 'Scene-Shifters' Manual', which provides intricate instruction as to how to construct a set and check sight lines in the theatre space. ${ }^{37}$ One further example is the detailed sound plot for Macbeth reproduced in the 'Guide to Amateur Theatrical Production' to exemplify the kind of aural accompaniment required for a New Hall play in performance. This demonstrates the precise and professional attention to stage management encouraged in her amateur practitioners:

Orchestra Time Plot

E.G. "Macbeth"

Overture: "Finlandia" 8 minutes

Act I Sc 1: Desert [sic] place. Leitmotif to take the curtain up 11/4 mins. Chopin's Prelude in $\mathrm{C}_{1} 3 \frac{3}{4}$ minutes

Sc 2: Palace of Forres

Sc 3: Blasted heath. Leitmotif as before.

Dvorak's New W. Symphony. $1^{1 / 2}$ minutes $^{38}$

Here Dolan guided student actors and musicians to realise intricate production practice, adopted from professional theatre work. Further evidence reinforces how focused she was on meeting professional standards as she advertises, in the 'Guide to Stage Management', how she promoted her qualifications when developing drama work at New Hall:

Reverend Mother told me they would place in my hands, as an expert in theatrical matters, the planning of a Stage in the new Gymnasium, worthy of New Hall's dramatic reputation.

Accordingly, I drew up a plan setting forth measurements, rake of Stage, gadgets etc. Etc., with meticulous detail. This I took with me to the architect in the City explaining the source of my authority together with my credentials as an expert. ${ }^{39}$

In the repeated insistence upon her qualifications and their application, Dolan not only records the development and achievements of her own working life, but also provides evidence of the type and breadth of professional expertise available to women theatre workers by the end of the nineteenth century. Her later career is one example of how this expertise 


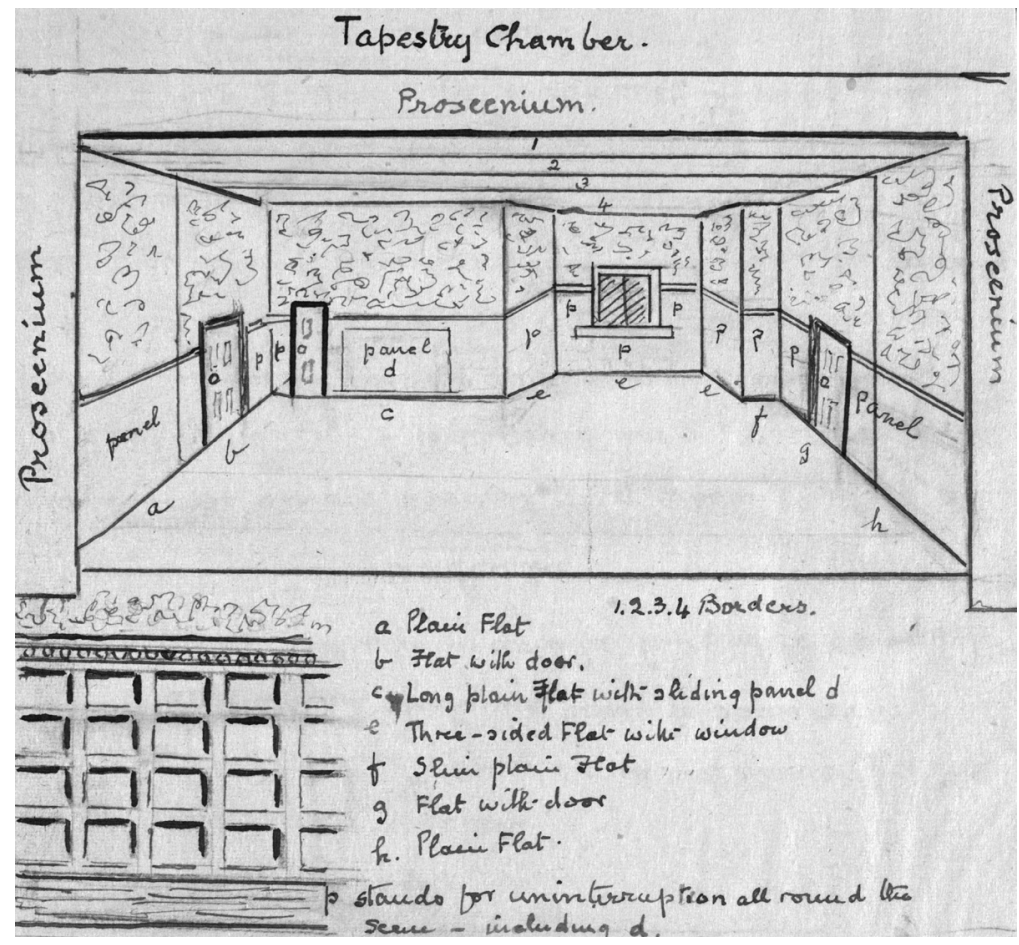

6 An example of the set designs developed by Winifred Dolan, taken from the 'Scene Plots Diagrams' section of the Winifred Dolan Collection.

was influencing subsequent theatre making, here within an educational environment.

\section{Expertise and New Hall repertoire}

Consistently, Dolan's focus is on translating texts into performance rather than other forms of activity, such as training exercises. Her interest was clearly in the redeployment of West End production practice, adapted to a specific context. The texts for production were canonical or of her own composition or adaptation, and some plays for young actors, including Toad of Toad Hall, are included in the collection, while plays written for production in professional theatre were not retained. Writing under the name Rothwell Haig (adapted from an area in her home city 
of Leeds), Dolan had written work for the professional theatre, and there is evidence that at least one of her plays was staged. Dolan continued to write after leaving the acting profession, and her play Kynaston's Wife was produced by Madge Kendal on tour in 1907, and then in revival for charity performances, as late as 1921 for Lord Haig's Officer's Association on 28 February of that year. ${ }^{40}$ The absence of this work from the collection further consolidates the idea that surviving materials were kept to sustain a particular kind of production practice at New Hall, influenced by but distinct from the professional theatre industry.

Both practice and repertoire were shaped by Dolan as producer, director and stage manager. She also performed the role of censor in preparing plays for a Catholic school environment, noting in relation to the production of Shakespeare:

A producer called upon to produce a classic has a much harder task than if called upon to produce a modern play. She has greater need of proficiency in technique and considerable scholarship [...] Shakespeare's plays have to be ruthlessly "cut" for School performance owing to time limit and because some of the text is unsuited to the lips of children, especially girls. ${ }^{41}$

The prompt books for Shakespeare productions included in the collection reinforce the measure of control exercised by Dolan, and include a number of precise directions for her actors that are categorised under specific headings. In the 'Guide to Amateur Theatrical Production' she emphasises that these are not the only, but rather the primary categories to consider when directing actors:
1. Business
2. Bye-play
3. Movements and positions
4. Exits and entrances
5. Music cues
6. Lighting cues (sometimes). ${ }^{42}$

Using these markers, Dolan was able to designate intricate levels of work. For example, the prompt book for Macbeth in the collection includes intricate 'Business' and 'Bye-play'. Business: 'During this scene down at door L. the Servants hand meat on spits to each guest. Then one with a flagon fills the goblets, leaving the flagon on the table: they all exeunt off up stage L.' Bye-play: 'Lady Macbeth has noticed that Macbeth has been called aside on some business and is worried about it. ${ }^{43}$ She also 
provided guidelines for acting technique, outlining for her amateur student-actors a necessary process from retention of information to articulation of performance:

Theory, alone, serves fully the purposes of the Critic and the Teacher, but it is inadequate to those of the Artist.

The critic may - the Artist dare not - part Theory from Practice.

For the Artist, they must go hand-in-hand, because there is a certain mechanical dexterity to be acquired before the beautiful conceptions he processes can be communicated to others.

Acting is an ear-directed and a mind-directed art; ear-directed in our study of it, mind-directed in our exercise of it.

BUT - his preparatory toil over, the actor must forget himself in his subject. He must let his voice henceforth be prompted NOT by the ear (however musical and exact it may be); but by his sympathy with the matter.

Similarly with his gestures, expression, poses and so on: they, also, must be prompted not by memory but by sympathy too.

All must come from WITHIN!

If this natural precept be overlooked the actor must not expect to gain much from his so-called study of elocution, gesture, and the rest! The Artist must digest his subject-matter before he can offer it to that successful assimilation by his audience which constitutes success. ${ }^{44}$

This not only suggests the attention to technique embedded in New Hall practice; it also portrays Dolan's work with the students as a producer concerned primarily with intricate and thoroughly rehearsed performance. Her expertise as an actress informs the precision of work presented by amateur cast members, the application of professional standards and the use of processes imported to promote sophisticated amateur theatre work.

An implicit and sustained argument for the necessary relationship between creativity and expertise is characteristic of the collection, as is the drive to argue for one presiding producer figure; authority over a production by one individual. This rearticulates the actor-manager model for use by Dolan in a specific environment; in the 'Guide to Stage Management', Dolan acknowledges the importance of collaboration while arguing that ultimate control should reside with a single individual:

May I give you a piece of advice? - Establish from the outset a spirit of collaboration. Let them realise the pecuniary value of the stuff they are handling and that, once spoilt, it cannot be replaced. Give your reasons 
for certain "insistings" when they obviously think you are just "being pernicketty"!

Make a point of being there, on the spot. Never "leave them to it"! ${ }^{45}$

The approach to stage management found in the guide attests to the conviction that regulation and control are integral to theatre making. This was also a characteristic of the kind of West End work Dolan regularly experienced in her earlier professional life, for example under Alexander, who implemented stringent practice - he consistently rehearsed his company for three hours each day in preparing a new production - and was consequently renowned for close management and supervision throughout the production process. ${ }^{46}$

Tracing a link between characteristic West End practice and the work conducted by Dolan does nothing to disrupt or challenge dominant perceptions of mainstream theatre, around the pre-eminence of the West End and the male theatre industry leaders operating there in the late nineteenth and early twentieth centuries: indeed, these are markers used by Dolan to authorise her subsequent work. Instead, material in the collection demonstrates how Dolan appropriated the forms of authority and practice she experienced as a subordinate employee in the West End, and implemented those qualities to work as a creative figurehead in a single location for three decades. Prior to Theatre in Education initiatives later in the twentieth century, the work of Dolan at New Hall demonstrated particular expertise in informing and propelling the introduction of regular and concerted drama work within a school environment. Dolan developed the materials which later formed the collection at a time when training in practice in schools and at the vocational, drama-school level was expanding. Women took prominent roles in this expansion as both teachers and students; as such the collection expresses not only a personal sense of professional authority, but also a desire to create a legacy at New Hall, through resources that would bequeath knowledge and mark her proficiency as a theatre maker in a specific context. Dolan was a producer figure who translated West End work into a subsequent career where professional agency and authority were profound, and this situates her as one kind of inheritor of the actor-manager role. Her work at New Hall exemplifies the expertise and professional dexterity that could be implemented by actresses negotiating the theatre industry and alternative career trajectories by the start of the twentieth century. 


\section{Notes}

1 Winifred Dolan, 'A Chronicle of Small Beer' [bound manuscript], 1949, V\&A Theatre and Performance Collection, The Winifred Dolan Collection, THM/394/1. Throughout this chapter, the Winifred Dolan Collection (hereafter referred to as 'the collection') has been used for all quotations, including Small Beer. Although this volume has been published (Dolan, 2010), the original handwritten version is the source for the quotations here. It includes distinctive features of punctuation and expression from Dolan's text, many of which were standardised for the 2010 edition. Archive materials are quoted as accurately as possible, employing features used by Dolan including upper-case letters and underlining for emphasis. This assists in examination of both the content and aims for the collection.

2 Prominent in the 'About Us - History' section of the school website is the following: 'School developments have included, for example, the Eaton Theatre, which was completed in 1925, with a stage and green room at one end and a studio above. The old theatre at New Hall was last used for the performance of "O what a lovely war", in December 1986. The refurbished Eaton Theatre was reopened in September 2008, with new tiered seating' (New Hall School, 2016).

3 There are a few, additional items that do not conform to type: Whittington of London, a historical novel, Dolan's handwritten notebook containing the poems she worked with for elocution classes (and there is a note in that book acknowledging that someone else at the school added this to the collection at a later date) and a mid-nineteenth-century collection of writing for children, The Child's Own Book, which, according to names inscribed, was a family heirloom.

4 For example, both Lena Ashwell and Elizabeth Robins experienced very different levels of success to Dolan as professional actresses. These three women held diverse personal and political beliefs when operating in West End theatre at the end of the nineteenth century, but there are similarities in how they wrote, later in life, about their experiences, employing a sense of distance as a way to demarcate their current practice and to historicise professional work on their own terms. This point of similarity in life writing by actresses of the era has been examined in Gale (2004) and Gardner (2004).

5 George Alexander, letter to Winifred Dolan [correspondence], no date, V\&A Theatre and Performance Collection, The Winifred Dolan Collection, $\mathrm{THM} / 394 / 7 / 3$.

6 Dolan, 'A Chronicle of Small Beer', p. 26.

7 Ibid., p. 68.

8 Austin (1835-1913) became poet laureate in 1896 after a delay in appointing someone to the role following the death of Tennyson in 1892. A prominent 
Conservative, he edited the National Review and publicly supported both Disraeli and Salisbury during their terms as prime minister.

9 Habitus: the interplay of social structure and individual activity according to class as defined by Bourdieu (1984).

10 George Alexander, letter to Alfred Austin [correspondence], c. 1892, V\&A Theatre and Performance Collection, The Winifred Dolan Collection, $\mathrm{THM} / 394 / 7 / 3$.

11 Dolan, 'A Chronicle of Small Beer', p. 61.

12 Ibid., p. 86.

13 Ibid., p. 215.

14 Producing work at another West End theatre was an unusual venture for Alexander; he staged the play at the Royalty (24 October 1896-16 January 1897) while The Prisoner of Zenda was running at the St James's Theatre. Alexander was motivated to mount this second production, at least in part, as a vehicle for the actor Fred Terry, whose wife Julia Neilson had been contracted by Alexander for work at the St James's. The offer of work to Terry was, according to Dolan, integral to Neilson's contract (Dolan, 'A Chronicle of Small Beer', p. 156).

15 Dolan, 'A Chronicle of Small Beer', p. 157.

16 Ibid., pp. 163-4.

17 George Alexander, letter to Winifred Dolan [correspondence], c. 1896, V\&A Theatre and Performance Collection, The Winifred Dolan Collection, THM/394/7/3; Dolan, 'A Chronicle of Small Beer', pp. 155, 166.

18 One example of such an exception would be the work of Helen Carte Boulter at the Savoy between 1875 and 1913.

19 Dolan, 'A Chronicle of Small Beer', pp. 156-61. The second theatre referred to here is the Royalty.

20 Ibid., p. 155.

21 Ibid., p. 235.

22 Ibid., p. 236.

23 de Bellaigue (2001) charts the altering professional field of teaching for women, using the personal writings of 83 school teachers working between 1780 and 1860 .

24 Winifred Dolan, 'Guide to Stage Management' [bound manuscript], 1945, V\&A Theatre and Performance Collection, The Winifred Dolan Collection, $\mathrm{THM} / 394 / 2 / 2$.

25 This tension between a perceived use for drama and anti-theatrical prejudice is examined by Bolton (2007: 45-62).

26 More fine detail on Catholic school autonomy and education legislation may be found in Tenbus (2008: 432-51).

27 For example, the ratio of female to male students at the Academy by 1909 was estimated at four women to one man (Barnes, 1958: 67).

28 Winifred Dolan, 'Guide to Amateur Theatrical Production' [bound 
manuscript], no date, V\&A Theatre and Performance Collection, The Winifred Dolan Collection, THM/394/2/1, foreword.

29 Winifred Dolan, 'The Shakespeare Coach's Manual' [manuscript], no date, V\&A Theatre and Performance Collection, The Winifred Dolan Collection, THM/394/5/3, p. 2.

30 Dolan, 'A Chronicle of Small Beer', p. 171.

31 Ibid., p. 149.

32 Winifred Dolan, 'Guide to Amateur Theatrical Production' [bound manuscript], no date, V\&A Theatre and Performance Collection, The Winifred Dolan Collection, THM/394/2/1.

33 Dolan, 'Guide to Stage Management', foreword.

34 An example of such a work would be Elsie Fogerty's 1907 adaptation of Tennyson's Princess, aimed primarily at girls' schools. The emergence of these guides receives more detailed coverage in Newey (1998: 93-111) and Cochrane (2011).

35 Irene Vanbrugh (1872-1949) was promoted within the company during the 1894 and 1895 seasons, and then recruited by Alexander as leading actress for nine productions between February 1906 and December 1915. Initially, she played Charley Wishanger in The Masqueraders (1894), Fanny in Guy Domville (1895), Gwendolyn in The Importance of Being Earnest (1895), Ellean in The Second Mrs. Tanqueray (1895) and Kate Merryweather in The Idler (1895). She returned to the theatre to play leading roles with the company after this period: Nina in His House in Order (1906), Marise in The Thief (1907), Dorothy Faringay in The Builder of Bridges (1908), Celia Faraday in Colonel Smith (1909), The Thief revival (1909), Zoe Blundell in Mid-Channel (1909), Cynthia Herrick in Open Windows (1913), His House in Order revival (1914) and Ottoline in The Big Drum (1915).

36 Dolan, 'Guide to Amateur Theatrical Production', p. 83.

37 Winifred Dolan, 'Scene-Shifters' Manual' [bound manuscript], no date, V\&A Theatre and Performance Collection, The Winifred Dolan Collection, $\mathrm{THM} / 394 / 2 / 3$.

38 Dolan, 'Guide to Amateur Theatrical Production', p. 227.

39 Dolan, 'Guide to Stage Management', foreword.

40 Dolan, 'A Chronicle of Small Beer', pp. 195-6.

41 Dolan, 'The Shakespeare Coach's Manual', pp. 1-2.

42 Dolan, 'Guide to Amateur Theatrical Production', p. 20.

43 Winifred Dolan, Macbeth prompt book [bound volume], no date, V\&A Theatre and Performance Collection, The Winifred Dolan Collection, $\mathrm{THM} / 394 / 3 / 3$.

44 Dolan, 'Guide to Amateur Theatrical Production', pp. 62-3.

45 Dolan, 'Guide to Stage Management', foreword.

46 The practice employed by Alexander of rehearsing from 11 until 2 is 
confirmed by Mason (1935: 24-5) and Dolan, 'A Chronicle of Small Beer', p. 66 .

\section{References}

Barnes, Kenneth (1958), Welcome, Good Friends, London: Peter Davies.

Bolton, Gavin (2007), 'A History of Drama Education: A Search for Substance', in Liora Bresler, ed., International Handbook of Research in Arts Education, Dordrecht: Springer, pp. 45-62.

Bourdieu, Pierre (1984), Distinction: A Social Critique of the Judgement of Taste, trans. Richard Nice, Cambridge, MA: Harvard University Press.

Bratton, Jacky (2003), New Readings in Theatre History, Cambridge: Cambridge University Press.

Canonesses of the Holy Sepulchre (2012), Fishy Tales: Living Memories of New Hall 1930-2012, Colchester: Canonesses of the Holy Sepulchre.

Cochrane, Claire (2011), Twentieth Century British Theatre: Industry, Art and Empire, Cambridge: Cambridge University Press.

De Bellaigue, Christina (2001), 'The Development of Teaching as a Profession for Women before 1870', The Historical Journal, 44.4, pp. 963-88.

Dolan, Winifred (2010), A Chronicle of Small Beer, ed. Andy Moreton, London: Society for Theatre Research.

Donohue, Joseph, and Ruth Berggren, eds (1995), Oscar Wilde's 'The Importance of Being Earnest': A Reconstructive Critical Edition of the Text of the First Performance, Gerrards Cross: Colin Smythe.

Gale, Maggie B. (2004), 'Lena Ashwell and Auto/Biographical Negotiations of the Professional Self, in Maggie B. Gale and Viv Gardner, eds, Auto/biography and Identity: Women, Theatre and Performance, Manchester: Manchester University Press, pp. 99-125.

Gardner, Viv (2004), 'The Three Nobodies: Autobiographical Strategies in the Work of Alma Ellerslie, Kitty Marion and Ina Rozant', in Maggie B. Gale and Viv Gardner, eds, Auto/biography and Identity: Women, Theatre and Performance, Manchester: Manchester University Press, pp. 10-38.

Mason, A. E. W. (1935), Sir George Alexander and the St. James's Theatre, London: Macmillan.

New Hall School (2016), 'About Us, History', http://www.newhallschool.co.uk/ History (accessed 4 December 2016).

Newey, Kate (1998), 'Home Plays for Ladies: Women's Work in Home Theatricals', Nineteenth Century Theatre, 26, pp. 93-111.

Tenbus, Eric G. (2008), 'Defending the Faith through Education: The Catholic Case for Parental and Civil Rights in Victorian Britain', History of Education Quarterly, 48.3, pp. 432-51.

Tuckwell, Tony (2006), New Hall and its School, King's Lynn: Free Range Publishing. 
Vanbrugh, Irene (1951), Hints on the Art of Acting, London: Hutchinson. Witz, Anne (1992), Professions and Patriarchy, London: Routledge.

\section{Archives}

\section{Victoria and Albert Museum}

George Alexander, letter to Alfred Austin [correspondence], c. 1892, V\&A Theatre and Performance Collection, The Winifred Dolan Collection, THM/394/7/3.

George Alexander, letter to Winifred Dolan [correspondence], c. 1896, V\&A Theatre and Performance Collection, The Winifred Dolan Collection, THM/394/7/3.

George Alexander, letter to Winifred Dolan [correspondence], no date, V\&A Theatre and Performance Collection, The Winifred Dolan Collection, $\mathrm{THM} / 394 / 7 / 3$.

Winifred Dolan, 'Guide to Stage Management' [bound manuscript], 1945, V\&A Theatre and Performance Collection, The Winifred Dolan Collection, $\mathrm{THM} / 394 / 2 / 2$.

Winifred Dolan, 'A Chronicle of Small Beer' [bound manuscript], 1949, V\&A Theatre and Performance Collection, The Winifred Dolan Collection, $\mathrm{THM} / 394 / 1$.

Winifred Dolan, 'Guide to Amateur Theatrical Production' [bound manuscript], no date, V\&A Theatre and Performance Collection, The Winifred Dolan Collection, THM/394/2/1.

Winifred Dolan, Macbeth prompt book [bound volume], no date, V\&A Theatre and Performance Collection, The Winifred Dolan Collection, $\mathrm{THM} / 394 / 3 / 3$.

Winifred Dolan, 'Scene-Shifters' Manual' [bound manuscript], no date, V\&A Theatre and Performance Collection, The Winifred Dolan Collection, $\mathrm{THM} / 394 / 2 / 3$.

Winifred Dolan, 'Scene Plot Diagrams' [miscellaneous illustrations, unbound], no date, V\&A Theatre and Performance Collection, The Winifred Dolan Collection, THM/394/2/4.

Winifred Dolan, 'The Shakespeare Coach's Manual' [manuscript], no date, V\&A Theatre and Performance Collection, The Winifred Dolan Collection, $\mathrm{THM} / 394 / 5 / 3$.

Winifred Dolan, 'Toad of Toad Hall' [manuscript], no date, V\&A Theatre and Performance Collection, The Winifred Dolan Collection, THM/394/6/1. 